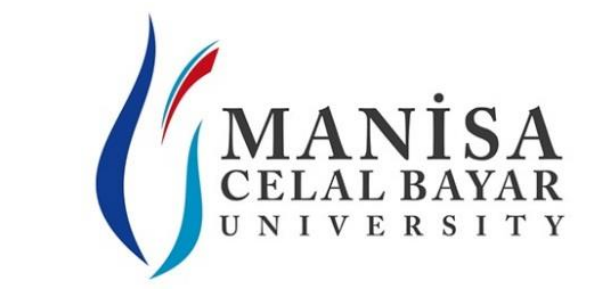

\title{
Journal of Science
}

Volume: 15, Issue: 3, Year: 2019

\author{
Contact \\ Manisa Celal Bayar University \\ Institute of Natural and Applied Sciences \\ Campus of Şehit Prof Dr İlhan Varank \\ 45140 Yunus Emre - MANISA, TURKEY \\ Tel: (00 90) 2362012700 \\ Fax: (00 90) 2362412149 \\ E-mail: cbujos@gmail.com \\ Web: http://dergipark.gov.tr/cbayarfbe
}

"CBU Journal of Science is indexed by ULAKBIM-TUBITAK TR-DIZIN"

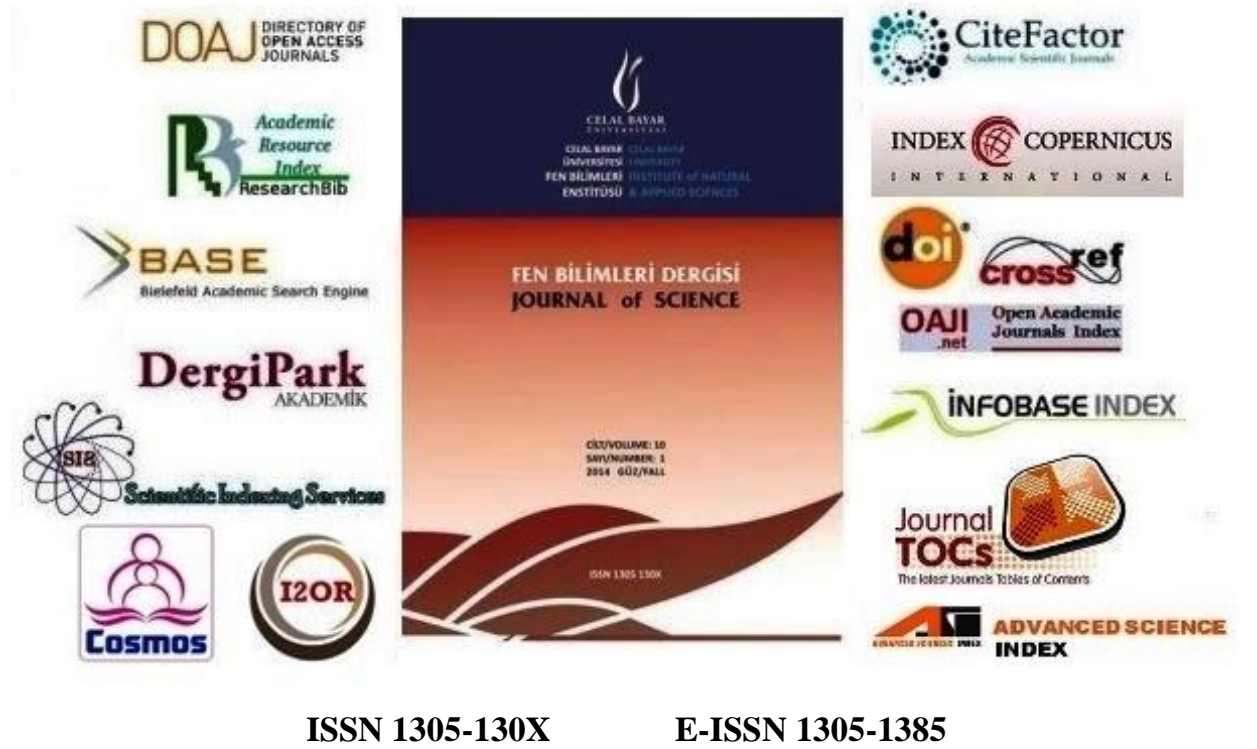

CBUJOS is published quarterly at Manisa Celal Bayar University Printing House

"CBU Journal of Science is a refereed scientific journal" 


\section{Celal Bayar University Journal of Science}

\section{Owner}

Prof. Dr. Kenan DOST, Manisa Celal Bayar University, Department of Chemistry on behalf of the Institute of Natural and Applied Sciences

\section{Editor}

Prof. Dr. Kenan DOST, Manisa Celal Bayar University, Department of Chemistry

Prof. Dr. Mustafa OSKAY, Manisa Celal Bayar University, Department of Biology

\section{Language Editor}

Asst. Prof. Dr. Ahmet Gökhan BİÇER, Manisa Celal Bayar University, Department of English Language and Literature

\section{International Scientific Advisory Board}

Prof. Dr. Thomas MAVROMOUSTAKOS, Chemistry Department of Kapodistrian University of Athens, Greece

Prof. Dr. Brahim HNICH, Izmir University of Economics, Faculty of Engineering and Computer Sciences, Department of Computer Engineering, İzmir, Turkey

Prof. Dr. Thamer Ahmad MOHAMMAD, Department of Civil Engineering, Faculty of Engineering, Universiti Putra Malaysia, Malaysia Assoc. Prof. Dr. Nur Izura UDZIR, Head of the Department of Computer Science, Faculty of Computer Science and Information Technology, Universiti Putra Malaysia, Serdang, Selangor, Malaysia

Assoc. Prof. Dr. Barbara MESSINA, Universita Degli Studi Di Salerno, Department of Civil Engineering, Salerno, Italy Assoc. Prof. Dr. Alyani Binti ISMAIL, Department of Computer and Communication Systems Engineering, Universiti Putra Malaysia, Serdang, Malaysia

Assoc. Prof. Dr. Zoran MARKOV, Faculty of Mechanical Engineering, University Ss. Cyril and Methodius in Skopje, Macedonia Asst. Prof. Dr. Donatella ALBANESE, Department of Industrial Engineering, University of Salerno, Italy Adj. Prof. Dr. Mary KALAMAKI, Division of Technology and Science, American College of Thessaloniki, Greece Dr Jens OLDELAND, Biocentre Klein Flottbek and Botanical Garden, University of Hamburg, Germany Dr Shri SHAJI, Department of Geology, University of Kerala, India

\section{National Scientific Advisory Board}

Prof. Dr. Brahim HNICH, Izmir University of Economics, Faculty of Engineering and Computer Sciences, Department of Computer Engineering, İzmir, Turkey

Prof. Dr. Erhan PESEN, Manisa Celal Bayar University, Department of Physics, Manisa, Turkey

Prof. Dr. Eşref DEMIR, Antalya Bilim University, Department of Material Science and Nanotechnology Engineering, Antalya, Turkey

Prof. Dr. Funda DEMIRHAN, Manisa Celal Bayar University, Department of Chemistry, Manisa, Turkey

Prof. Dr. Neriman BAĞDATLIOĞLU, Manisa Celal Bayar University, Department of Food Engineering, Manisa, Turkey

Prof. Dr. Sezai TAŞKIN, Manisa Celal Bayar University, Department of Electrical and Electronics Engineering, Manisa, Turkey

Prof. Dr. Şenay AYDIN, Manisa Celal Bayar University, Department of Agricultural Sciences, Alaşehir, Manisa, Turkey

Assoc. Prof. Dr. Ali KONURALP, Manisa Celal Bayar University, Department of Mathematics, Manisa, Turkey

Assoc. Prof. Dr. Hülya DURMUŞ, Manisa Celal Bayar University, Engineering Faculty, Materials Engineering Department, Manisa, Turkey

Assoc. Prof. Dr. Murat UYGUN, Adnan Manderes University, Koçarlı Vocational School, Aydın, Turkey

Assoc. Prof. Dr. Pınar MIZRAK ÖZFIRAT, Manisa Celal Bayar University, Engineering Faculty, Industrial Engineering Department, Manisa, Turkey Asst. Prof. Dr. Gülen Yıldız TURP, Ege University, Department of Food Engineering, İzmir, Turkey

Asst. Prof. Dr. Hilal YILDIZ, Nevşehir Hacı Bektaş Veli University, Faculty of Engineering and Architecture, Food Engineering Department, Nevşehir, Turkey

Asst. Prof. Dr. İlhan BAŞTÜRK, Adnan Menderes University, Faculty of Engineering, Elekectrical and Electronics Engineering, Aydın, Turkey Asst. Prof. Dr. Levent PARALI, Manisa Celal Bayar University, Electronics and Automation Department, Manisa, Turkey Asst. Prof. Dr. Soner ŞEKER, Uşak University, Engineering Faculty, Civil Engineering Department, Uşak, Turkey 


\section{CBU Journal of Science}

CBU Journal of Science is a refereed scientific journal published four times annually (March, June, September and December) by Institute of Natural and Applied Sciences of Manisa Celal Bayar University. Articles are written in English are accepted to be evaluated.

Articles are accepted related to scientific areas below;

Basic and Applied Sciences (Physics, Chemistry, Biology, Mathematics, Statistics etc.), Engineering Sciences (Mechanical, Civil, Food, Industrial, Electrical and Electronic etc.)

CBU Journal of Science is indexed by TUBITAK ULAKBIM TR-DIZIN, and also is included in DOAJ, Cite Factor, Journal TOCS, Advanced Science Index and OAJI databases. Digital Object Identifier (DOI) number will be assigned for all the articles being published in CBU Journal of Science.

Instructions for Authors and Article Template can be found on the main page of MCBU Institute of Natural and Applied Sciences (http://fbe.cbu.edu.tr) 
Vol: 15, Issue: 3, Year: 2019

\section{Contents}

Research Articles

Determination of Operating Conditions for Hydrogen Peroxide and Hydroxyl Radical Production in Electro-peroxone Process

(Research Article)

DOI: 10.18466/cbayarfbe. 395273

Özge Dinç, Zeynep Girgin Ersoy, Hazal Öztürk, Sibel Barışçı

Mathematical Modelling of Electrically Driven Elevator via Linear Graph Method, Dynamic Response Analysis and Active Vibration Control

(Research Article)

DOI: $10.18466 /$ cbayarfbe.449655

Mustafa Oğuz Nalbant, Semih Sezer

Effects of Nano-Lubricants on Power and CO Emission of a Diesel Engine: An Experimental Investigation

(Research Article)

DOI: $10.18466 /$ cbayarfbe.453763

\section{Ali Can Y1lmaz}

Oxygen Reduction at Palladium Decorated Copper-Molybdenum Oxide Modified Glassy Carbon Electrode

(Research Article)

DOI: 10.18466/cbayarfbe.529847

\section{K. Volkan Özdokur}

Viable Airborne Fungi of Outdoor Environments of Yunusemre District, Manisa, Turkey

(Research Article)

DOI: 10.18466/cbayarfbe.538722

Fatih Kalyoncu

Sodium Arsenic Alters the Gene Expression of some Steroidogenic Genes in TM3 Leydig Cell

(Research Article)

DOI: 10.18466/cbayarfbe.540544

Tunahan Taşçı, Vahap Eldem, Melike Erkan

A Hybrid Approach for Large-scale Fabrication of Paper-based Electrochemical Assays for Biomedical Diagnosis

(Research Article)

DOI: $10.18466 /$ cbayarfbe.542120

Fariba Ghaderinezhad, Savas Tasoglu 
Does Exogenously Applied Gallic Acid Regulate the Enzymatic and Non-Enzymatic Antioxidants in Wheat Roots Exposed to Cadmium Stress?

(Research Article)

DOI: $10.18466 /$ cbayarfbe. 554860

Ceyda Ozfidan Konakci

Markov Model Based Real Time Speaker Recognition using K-Means, Fast Fourier Transform and Mel Frequency Cepstral Coefficients

(Research Article)

DOI: $10.18466 /$ cbayarfbe. 556936

Emin Borandağ

Localization of Laminin and Fibronectin in Rat Testes after Diisobutyl Phthalate Exposure:

Histopathologic and Immunohistochemical Study

(Research Article)

DOI: 10.18466/cbayarfbe.570613

Yücel Başımoğlu Koca

Calcium Phosphate Mineralization on Calcium Carbonate Particle Incorporated Silk-Fibroin Composites

(Research Article)

DOI: 10.18466/cbayarfbe.573625

Derya Kapusuz, Batur Ercan

Pretreatment of Food Industry Wastewater by Coagulation: Process Modeling and Optimization

(Research Article)

DOI: 10.18466/cbayarfbe.581611

Senem Yazıcı Güvenç, Emine Can Güven

Antimicrobial Potentials of Phyto-synthesized Silver Nanoparticles from Laurus nobilis L.

(Research Article)

DOI: $10.18466 /$ cbayarfbe. 582161

Melisa Ayışı̆̆ı, Tansel Yalçın, Lale Yıldız Aktaş 